\title{
A Practical Guide to Early Numeracy Instruction for General and Special Educators
}

\author{
Alida Anderson ${ }^{1}$ \\ ${ }^{1}$ School of Education, Teaching, and Health, American University, Washington D.C., USA \\ Correspondence: Alida Anderson, School of Education, Teaching, and Health, American University, 4400 \\ Massachusetts Ave. NW, Washington DC 20016. E-mail: aanderso@american.edu
}

Received: November 13, 2012 Accepted: November 22, 2012 Available online: January 6, 2013

doi:10.11114/jets.v1i1.18

URL: http://dx.doi.org/10.11114/jets.v1i1.18

\begin{abstract}
This report summarizes recommendations from NCTM, NRC, CCSSM, NMAP, and IES to guide early numeracy instruction for elementary age students in general and special education classroom settings. We highlight common threads among general and special education research recommendations and provide a numeracy intervention curriculum model connecting intervention and instructional principles.
\end{abstract}

Keywords: mathematics, special education, elementary, curriculum, intervention

\section{Introduction}

This article focuses on research and recommendations from prominent organizations for curriculum and instruction in whole number numeracy, a critical foundation for all mathematics learning. As the Common Core State Standards in Mathematics (CCSSM) issue a new vision of mathematics education for all students, early numeracy warrants our increased attention. The purpose of this paper is to synthesize research and recommendations from the National Council of Teachers of Mathematics (NCTM), National Research Council (NRC), National Math Advisory Panel (NMAP), and the CCSSM initiative for application to inclusive classrooms and intervention settings with elementary school age children.

\section{Numeracy Standards for All}

Since 1989, when NCTM initiated the standards movement with their landmark publication, Curriculum Standards for School Mathematics, the United States has been moving steadily toward a common core of standards in mathematics, a movement that has been accelerated by the consistently poor record of mathematics achievement shown by American students on large-scale national and international tests (NCES, 2007). Due to the serious consequences of a growing population poorly prepared in the disciplines requiring a strong mathematics background (e.g., STEM fields), NCTM (1989; 1991; 1995; 2000; 2006), NMAP (2008), and the NRC (2001; 2006) have recommended content, instruction, and assessment to put students on the path to improved mathematics achievement. The CCSSM (2010) initiative led by the National Governors Association and the Council of Chief State School Officers replaces the patchwork of state-based standards contributing to uneven mathematics achievement across the country. These standards are intended to guide curriculum and professional development over the years ahead.

\section{Broad Learning Outcomes in Early Numeracy}

Recommendations from the CCSSM, NCTM, NRC, and NMAP collectively inform our thinking about how to redesign mathematics curriculum and instruction. Notable is their consensus on the broad learning outcomes of K-12 mathematics education: conceptual understanding, computational fluency, and problem solving skill. The recommendations for early numeracy content that support broad outcomes in conceptual understanding, computational fluency, and problem solving have two central emphases: place value and basic arithmetic operations.

Place value (grouping by tens, using multi-digit numerals to represent quantity) plays a central role in the base-ten system and serves as the principal anchor for all base-ten instruction. Figure 1 below shows how topics often taught independently of one another can be taught using place value as the organizing instructional principle to facilitate connection-making. Students' deep understanding of place value supports their fluency 
with addition, subtraction, multiplication, and division, as well as reasoning skills underlying mathematical thinking and successful problem solving.

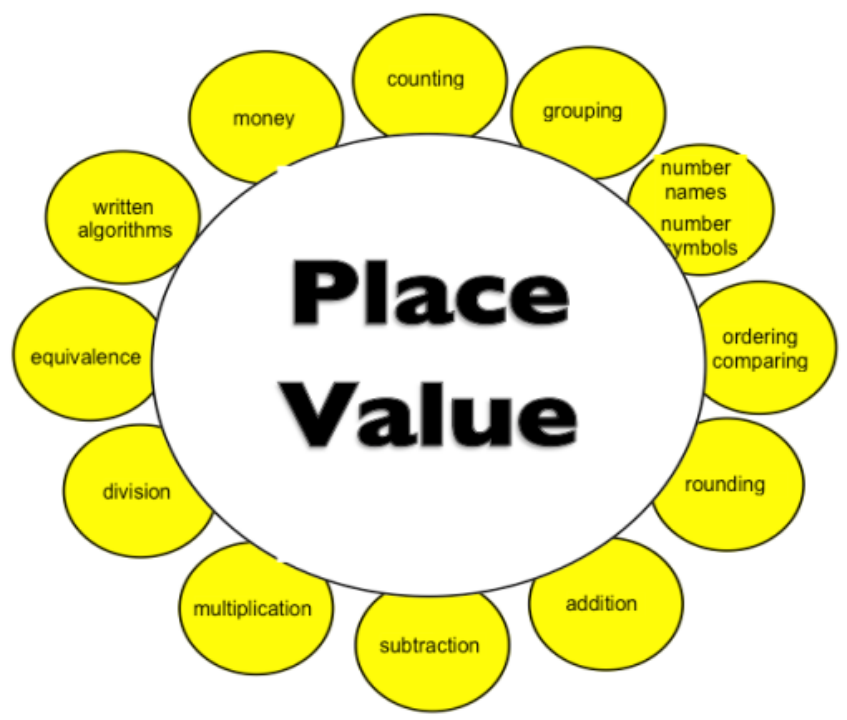

Figure 1. Place value as the organizing principle for curriculum and instruction

With place value and basic operations as the core of early numeracy content (Cooper \& Tomayko, 2011), recommendations from NCTM, NMAP, NRC, and CCSSM provide guidance for instruction with curricular emphasis on:

-Explicit instruction (clear, systematic, interactive, and carefully scaffolded)

-Physical models (base-ten manipulatives to aid conceptual understanding)

-Frequent practice (following substantial experiences that stress thinking strategies)

\section{Guiding Intervention Principles}

Arguably the most compelling aspect of a strong early numeracy curriculum is its capacity to teach for understanding at all levels of instruction (i.e., general and special education). In the past decade, both general and special education researchers and practitioners have identified the value of response-to-intervention (RtI) systems to address the diverse learning needs of students struggling in mathematics (Fuchs \& Fuchs, 2006; 2007). This claim is supported by the research on tiered instructional interventions, which are designed to improve instruction for all students. While RtI addresses the learning needs of all students, it identifies struggling students, including those with and those without disabilities, for intervention earlier and more reliably than conventional "wait and see" approaches (Bradley \& Danielson, 2004; Gartland \& Strosnider, 2005; Simeonsson, 1994).

Response-to-intervention embeds universal design for learning (UDL) principles, in which curriculum and intervention approaches are intended to meet the needs of all children in Tier 1 inclusive classroom settings (Fuchs \& Fuchs, 2001). In incorporating UDL principles in RtI mathematics instruction, the hope is for early prevention of mathematics difficulties (Lee, Grigg, \& Dion, 2007; NCTM, 2007). A tiered approach to intervention, such as RtI, is prevention directed at both students unresponsive due to their learning disabilities and students struggling in mathematics for other reasons (i.e., failure due to instructional gaps, environmental factors, and language-learning difficulties). In this way, RtI holds promise similar to the promise implied of recommending organizations — that early numeracy understanding and skills prevent mathematics failure.

Research on the implementation of RtI in mathematics points to useful features for guiding effective inclusive and intervention mathematics practices (Riccomini \& Witzel, 2010). Table 1 summarizes this research, in which there are variations among key intervention features in classroom size/student-teacher ratio, repeated instruction and practice, amount of discovery learning and direct instruction, instructional pace and sequence (e.g., scaffolding of lessons and teaching of discrete skills), and use of concrete representations (e.g., manipulatives). 
Table 1. Mathematics RtI features

\begin{tabular}{|c|c|c|c|}
\hline $\begin{array}{l}\text { Intervention } \\
\text { Features }\end{array}$ & Tier 1 & Tier 2 & Research \\
\hline \multirow{2}{*}{$\begin{array}{l}\text { Student-teacher } \\
\text { ratio }\end{array}$} & -Large group & •Individualized & •Butler et al. (2001) \\
\hline & $\cdot 1: 30$ & $• 1: 3-1: 6$ & •Kroesenbergen \& Van Luit (2003) \\
\hline \multirow{4}{*}{$\begin{array}{l}\text { Repeated } \\
\text { instruction }\end{array}$} & \multirow{2}{*}{$\begin{array}{l}\text { •Focus on concepts, } \\
\text { application, extension }\end{array}$} & •Repeated practice in lessons & •Mayfield \& Chase (2002) \\
\hline & & •Content repeated in lessons & •Miller \& Mercer (1997) \\
\hline & \multirow{2}{*}{$\begin{array}{l}\bullet \text { Homework to } \\
\text { reinforce learning }\end{array}$} & \multirow{2}{*}{$\begin{array}{l}\text {-Instructional patterning, approach, } \\
\text { delivery in lessons }\end{array}$} & \multirow{2}{*}{$\begin{array}{l}\text { •Sood \& Jitendra (2006) } \\
\text { •Garnett (1998) }\end{array}$} \\
\hline & & & \\
\hline \multirow[t]{3}{*}{ Direct instruction } & \multirow{3}{*}{$\begin{array}{l}\text { - Combined discovery and } \\
\text { direct instruction }\end{array}$} & -Stepwise procedures & •Gersten \& Chard (1999) \\
\hline & & •Prompts provided & •Carnine (1997) \\
\hline & & & •Witzel et al. (2003) \\
\hline \multirow[t]{3}{*}{ Instructional pace } & •Rapid presentation & •Lesson details govern pace & •Cawley \& Miller (1989) \\
\hline & \multirow{2}{*}{$\begin{array}{l}\text { •Skills taught through } \\
\text { activities }\end{array}$} & •Repeated lesson content & •Woodward (2004) \\
\hline & & •Mastery requirement & •Woodward \& Montague (2002) \\
\hline \multirow{3}{*}{$\begin{array}{l}\text { Instructional } \\
\text { sequence }\end{array}$} & •Spiral, non & \multirow{2}{*}{$\begin{array}{l}\text {-Sequenced lessons fill and prevent } \\
\text { knowledge gaps }\end{array}$} & •Darch et al. (1984) \\
\hline & •Concepts/topics & & •Jones et al. (1997) \\
\hline & Reintroduced & •Content in discrete units & •Whitehurst (2003) \\
\hline \multirow[t]{2}{*}{$\begin{array}{l}\text { Concrete } \\
\text { representation }\end{array}$} & \multirow[t]{2}{*}{$\begin{array}{l}\text { •Multiple models } \\
\text { •Implicit generalization }\end{array}$} & \multirow{2}{*}{$\begin{array}{l}\text {-Common physical model (Unifix, } \\
\text { Digi-Block, KP tiles) used to teach } \\
\text { concepts, skills }\end{array}$} & $\begin{array}{l}\text { •Kroesenbergen \& Van Luit } \\
(2003)\end{array}$ \\
\hline & & & •Fennel \& Landis (1994) \\
\hline
\end{tabular}

\section{Piloting a Numeracy Intervention Curriculum: Lesson from the Field}

In the following example of a place value lesson in an inclusive first grade classroom, we demonstrate how instruction in grouping by tens can be adapted to meet the instructional needs of students in Tiers 1-3 (see Figure 2).

\section{Objectives}

- $\quad$ Draw the tile representation of a three-digit number (Tier 1 students).

- Draw the tile representation of a two-digit number (Tier 2 students).

- Use tiles to show that ten ones and one ten have the same value (Tier 3 students).

\section{Activities}

First grade students in Tiers 1-3 participate in the number-building lesson, each student engaging in the activities at their appropriate level of complexity and challenge.

(a) Students count 1-tiles onto a small ten-frame platform to discover the unique appearance of quantities 1 to 10 .

(b) They make tiles-of-10 by grouping each full ten-frame (ten 1-tiles) with a yellow grouping tile, demonstrating that ten ones and one ten are equivalent.

(c) When students are stable with this concept, they repeat the operation by counting ten tiles-of 10 onto a larger ten-frame platform. 
(d) They make a tile-of-100 by grouping the full ten-frame (ten tiles-of-10) with a blue grouping tile, demonstrating that one tile-of-100, ten tiles-of-10, and 100 1-tiles are equivalent.

(e) Students use drawings and numerals to demonstrate their understanding.

a.

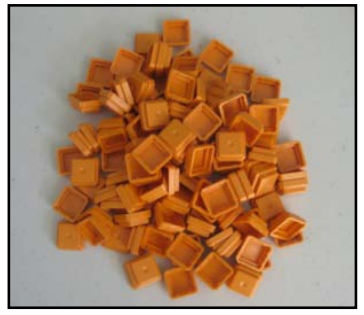

c.

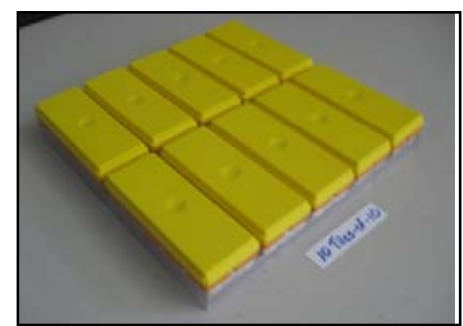

b.
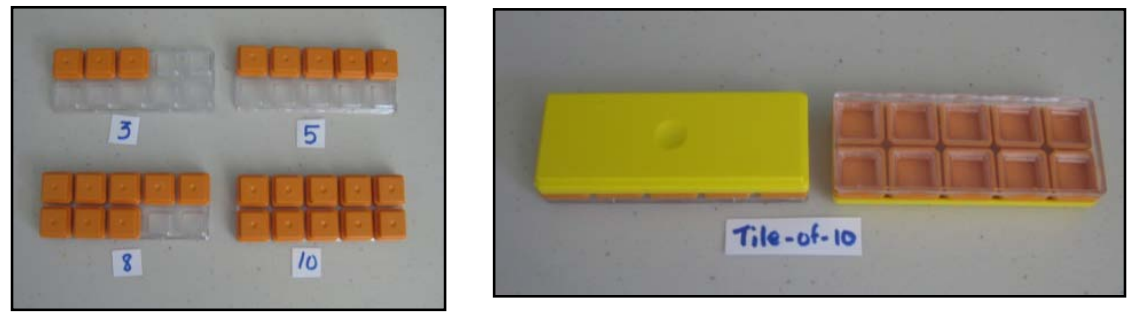

d.

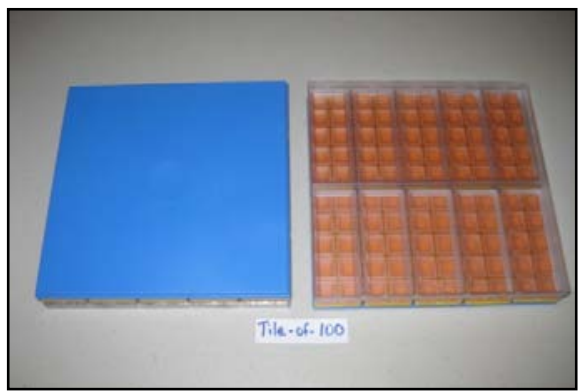

Tier 1 students use the sequence (a-d above) to build two-and three-digit numbers, drawing the tiles onto printed ten-frames and labeling their drawings with numerals. They indicate equivalences under each ten-frame (e, below).

e.

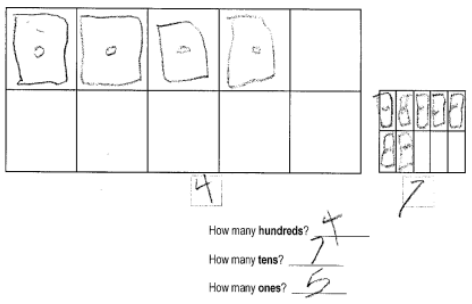

5

Tier 2 students need additional time, experience, and practice to build instant recognition of different quantities of 1-tiles on the ten-frame (a prerequisite for recognizing similar formations among the places) and to demonstrate the understanding that ten ones and one ten have the same value.

e.
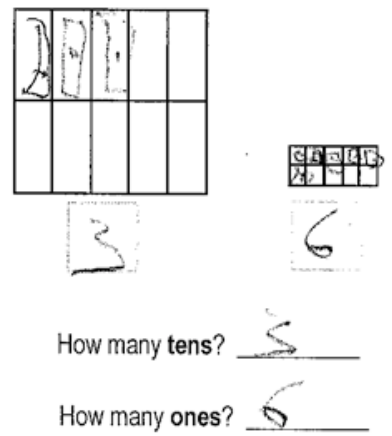

Tier 3 students need multiple opportunities to count 1-tiles onto the ten-frame and recognize each quantity from its formation without counting. They fill ten-frames with ten-1-tiles and snap the yellow grouping tile onto a full ten-frame, but it takes time before they show understanding that ten 1-tiles and one tile-of-10 show the same quantity. 

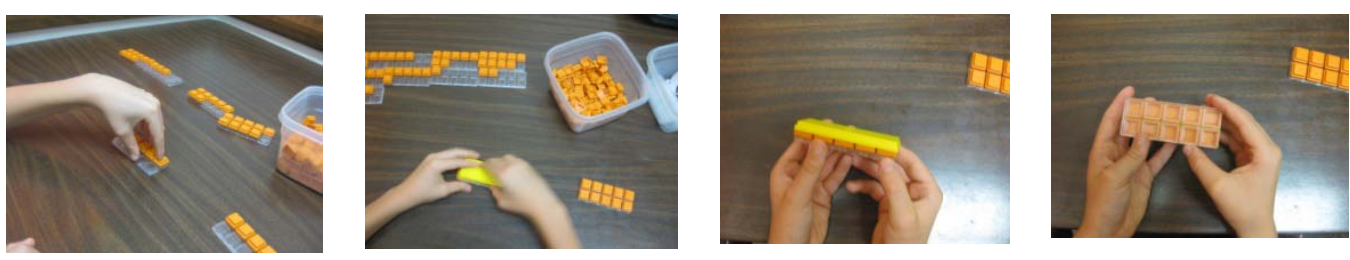

Figure 2. Grouping by tens: The foundation of place value

\section{Components of an 'Ideal' Numeracy Intervention Curriculum}

From the collective recommendations of CCSSM, NCTM, NRC, and NMAP discussed previously, and resulting from our pilot research with elementary age students, we have derived the strands of an ideal early numeracy curriculum as follows:

- Broad learning outcomes for all mathematics students (conceptual understanding, procedural fluency, and problem solving skills);

- Early numeracy content (place value and basic operations) and instructional approaches (explicit instruction, physical models, articulation of principles, frequent thought-based practice) that reflect UDL principles in both scope and depth of focus; and

- $\quad$ Essential intervention elements for struggling elementary and middle school students (see Figure 3).

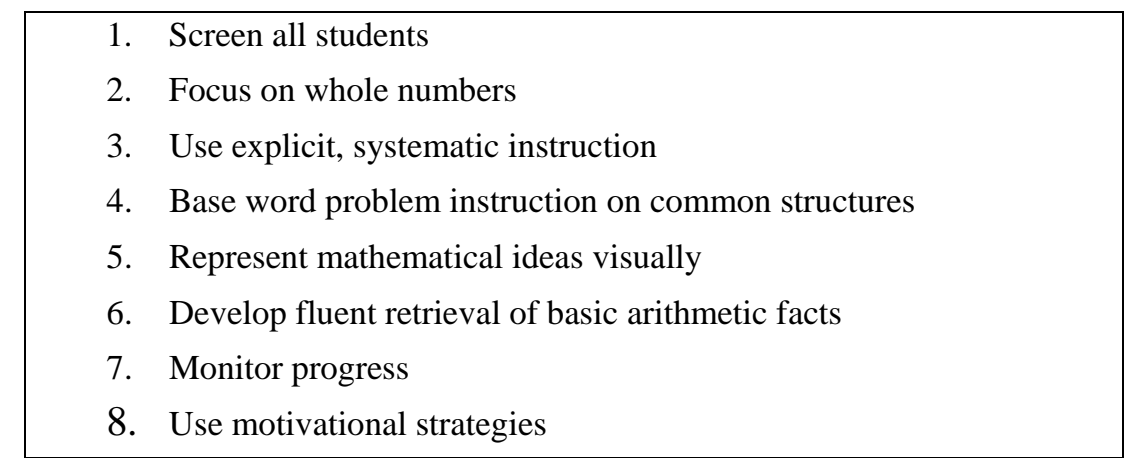

Figure 3. Institute of Educational Sciences (IES) recommendations for working with students struggling with elementary and middle school mathematics (Gersten et al., 2009)

These features, taken together, constitute a numeracy curriculum that weaves together the broad learning outcomes, early numeracy content and instruction, and essential intervention elements. We can have confidence in its effectiveness both as an early numeracy curriculum for all students and as an intervention to prevent likely mathematics failure. The features of this curriculum are listed in Table 2 below.

Table 2. Curriculum Model Integrating Early Numeracy Instruction and Intervention Elements

\begin{tabular}{|c|c|c|c|}
\hline \multirow[b]{2}{*}{ Curriculum Model } & \multicolumn{2}{|c|}{$\begin{array}{l}\text { Early Numeracy Instruction } \\
\text { (NCTM, NRC, NMAP, CCSSM) }\end{array}$} & \multirow{2}{*}{$\begin{array}{c}\text { Essential } \\
\text { Intervention } \\
\text { Elements } \\
\text { (IES) }\end{array}$} \\
\hline & $\begin{array}{c}\text { Broad math } \\
\text { instructional } \\
\text { outcomes }\end{array}$ & $\begin{array}{c}\text { Early } \\
\text { numeracy } \\
\text { content }\end{array}$ & \\
\hline $\begin{array}{l}\text { 1. Diagnostic assessment to identify knowledge and } \\
\text { skill gaps }\end{array}$ & & & $\sqrt{ }$ \\
\hline 2. Coherent, sequenced instruction & & $\sqrt{ }$ & $\sqrt{ }$ \\
\hline 3. Explicit focus on base ten and place value in early & $\sqrt{ }$ & $\sqrt{ }$ & $\sqrt{ }$ \\
\hline
\end{tabular}


grades

4. Concrete, pictorial, and abstract representations of mathematical ideas

5. Use of manipulatives

6. Development of reasoning skills

7. Opportunities for students to communicate their mathematical understanding

8. Targeted progress monitoring

9. Application of mathematical concepts to contextual problems

10. Frequent practice

\section{Conclusion}

A critical aspect of an ideal early numeracy curriculum is its ability to teach for deep understanding at all levels of instruction and intervention (i.e., general and special education). This ideal meets the demands of an inclusive environment in which all students have access to challenging standards and, at the same time, targets weakness in the existing curriculum structure. Such weakness was noted when American College Testing (ACT), Inc. studied the ACT scores of students in the "college ready" range on items correlated to the CCSSM, they determined that the weakest math area was number and quantity, where only $34 \%$ of students showed proficiency in skills considered foundational to later math study (Gewertz, 2011). Clearly, the implications of this stunning fact demand our serious attention.

\section{References}

Bradley, R., \& Danielson, L. (2004). The Office of Special Education Program's LD initiative: A context for inquiry and consensus. Learning Disability Quarterly, 27 (4), 186-88. http://dx.doi.org/10.2307/1593671

Butler, F. M., Miller, S. P., Lee, K., \& Pierce, T. (2001). Teaching mathematics to students with mild-to-moderate mental retardation: A review of the literature. Mental Retardation, 39 (1), $20-31$. http://dx.doi.org/10.1352/0047-6765(2001)039<0020:TMTSWM>2.0.CO;2

Carnine, D. (1997). Instructional design in mathematics for students with learning disabilities. Journal of Learning Disabilities, 30 (3), 130-41. http://dx.doi.org/10.1177/002221949703000201

Cawley, J., \& Miller, J. H. (1989). Cross-sectional comparisons of the mathematical performance of children with learning disabilities: Are we on the right track toward comprehensive programming? Journal of Learning Disabilities, 22 (4), 250-54. http://dx.doi.org/10.1177/002221948902200409

Center for Applied Special Technology (CAST). (2008). Universal design for learning guidelines version 1.0, Wakefield, MA.

Cooper, L. L., \& Tomayko, M. C. (2011). Understanding place value: Exploring ancient numbers helps students focus on the structure and properties of our Hindu-Arabic system. Teaching Children Mathematics, 17 (9), 558-68.

Darch, C., Carnine, D., \& Gersten, R. (1984). Explicit instruction in mathematics problem solving. Journal of Educational Research, 77 (6), 351-59.

Fennel, F. S., \& Landis, T. D. (1994). Number and operation sense. In C.A. Thornton and N. S. Bley (Eds.). Windows of opportunity: Mathematics for students with special needs (pp. 187-203). Reston, VA: NCTM.

Fuchs, D., \& Fuchs, L. (2006.) A framework for building capacity for responsiveness to intervention. School Psychology Review, 35 (4), 621-26.

Fuchs, L., \& Fuchs, D. (2007). A model for implementing responsiveness to intervention. Teaching Exceptional Children, 39 (5), 14-20.

Fuchs, L., \& Fuchs, D. (2001). Principles for the prevention and intervention of mathematics difficulties. Learning Disabilities Research \& Practice, 16 (2), 85-95. http://dx.doi.org/10.1111/0938-8982.00010

Garnett, K. (1998). Math learning disabilities. Reprinted from the Division of Learning Disabilities Journal of CEC. Available at: www.ldonline.org/article/5896. 
Gartland, D., \& Strosnider, R. (2005). NJCLD position paper: Responsiveness to intervention and learning disabilities. Learning Disability Quarterly, 28 (4), 249-60. http://dx.doi.org/10.2307/4126964

Gersten, R., \& Chard, D. (1999). Number sense: Rethinking arithmetic instruction for students with mathematical disabilities. Journal of Special Education, 33 (1), 18-28. http://dx.doi.org/10.1177/002246699903300102

Gersten, R., Beckmann, S., Clarke, B., Foegen, A., Marsh, L., Star, J. R., \& Witzel, B. (2009). V Assisting students struggling with mathematics: Response to intervention (RtI) for elementary and middle schools (NCEE). Washington, DC: National Center for Education Evaluation and Regional Assistance, Institute of Education Sciences, U.S. Department of Education.

Gewertz, C. (2011). Most students failing to reach common-standards bar. Education Week, 30 (15), 10-11.

Jones, E. D., Wilson, R., \& Bhojwani, S. (1997). Mathematics instruction for secondary students with learning $\begin{array}{llllll}\text { disabilities. Journal of } & \text { Learning }\end{array}$ http://dx.doi.org/10.1177/002221949703000203

Kroesbergen, E. H., \& Van Luit, J. E.H. (2003). Mathematics interventions for children with special needs: A $\begin{array}{lllll}\text { meta-analysis. Remedial and Special Education, } 24 & \text { (2), 97-114. }\end{array}$ http://dx.doi.org/10.1177/07419325030240020501

Lee, J., Grigg, W. S., \& Dion, G. S. (2007). The nation's report card: Mathematics 2007 (NCES). National Center for Education Statistics, Institute of Education Sciences, U.S. Department of Education, Washington, D.C.

Mathematics Learning Study Committee, National Research Council. (2001). Adding it up: Helping children learn mathematics. Washington, DC: National Academy Press.

Mathematics Learning Study Committee, National Research Council. (2006). Adding it up: Helping children learn mathematics ( $6^{\text {th }} E d$.). Washington, DC: National Academy Press.

Mayfield, K. H., \& Chase, P. N. (2002). The effects of cumulative practice on mathematics problem solving. Journal of Applied Behavior Analysis, 35 (2), 105-23. http://dx.doi.org/10.1901/jaba.2002.35-105

Miller, S. P., \& Mercer, C. D. (1997). Educational aspects of mathematics disabilities. Journal of Learning Disabilities, 30 (1), 47-56. http://dx.doi.org/10.1177/002221949703000104

Montague, M. (1991). The effects of cognitive and metacognitive strategy instruction on the mathematical problem-solving of middle school students with learning disabilities. Journal of Learning Disabilities, 25 (4), 230-48.

National Center for Educational Statistics (NCES). (2006). Issue brief: Instructional focus in first grade. Jessup, MD.

National Council of Teachers of Mathematics. (1989). Curriculum and evaluation standards for school mathematics. Reston, VA.

National Council of Teachers of Mathematics. (1991). Professional standards for teaching mathematics. Reston, VA.

National Council of Teachers of Mathematics. (1995). Assessment standards for school mathematics. Reston, VA.

National Council of Teachers of Mathematics. (2000). Principles and standards for school mathematics. Reston, VA.

National Council of Teachers of Mathematics. (2006). Curriculum focal points for prekindergarten through grade 8 mathematics: A quest for coherence. Reston, VA.

National Governors Association and the Council of Chief State School Officers. (2010). Common core state standards for mathematics. Washington, DC: Author. Available at: www.corestandards.org/the-standards/mathematics

National Math Advisory Panel (NMAP). (2008). Foundations for success: The final report of the National Mathematics Advisory Panel. Washington, DC: U.S. Department of Education.

Riccomini, P. J., \& Witzel, B. S. (2010). Response to Intervention in Math. Thousand Oaks, CA: Corwin.

Simeonsson, R. J. (1994). Risk, resilience and prevention: Promoting the well-being of all children. Baltimore, 
MD: Brookes.

Sood, S., \& Jitendra, A. K. (2007). A comparative analysis of number sense instruction in reform-based and traditional mathematics textbooks. Journal of Special Education, 41 (3), 145-57. http://dx.doi.org/10.1177/00224669070410030101

Whitehurst, G. (2003). Papers, presentations, mathematics and science initiative. Washington, DC: U.S. Government Printing Office. Available at: www.ed.gov/rschstat/research/progs/mathscience/whitehurst.html

Witzel, B., Mercer, C. D., \& Miller, D. M. (2003). Teaching algebra to students with learning difficulties: An investigation of an explicit instructional model. Learning Disabilities Research and Practice, 18 (2), 121-31. http://dx.doi.org/10.1111/1540-5826.00068

Woodward, J. (2004). Mathematics education in the United States: Past to present. Journal of Learning Disabilities, 37 (1), 16-31. http://dx.doi.org/10.1177/00222194040370010301

Woodward, J. \& Montague, M. (2002). Meeting the challenge of mathematics reform for students with LD. Journal of Special Education, 36 (2), 89-101. http://dx.doi.org/10.1177/00224669020360020401

\section{(cc) $\mathrm{EY}$}

This work is licensed under a Creative Commons Attribution 3.0 License. 